\title{
SUSTAINABILITY REPORTING DISCLOSURE PRACTICES AMONG BANGLADESHI COMPANIES IN LINE WITH GLOBAL REPORTING INITIATIVES
}

\author{
SUMON KUMAR DAS1, * \\ MASUM MIAH ${ }^{1}$ \\ MD. RUBEL MIAH ${ }^{1}$ \\ DILJAHAN AKTER1 \\ TANVIR HOSSAIN ${ }^{1}$
}

Received: 12 December 2019 / Revised: 3 April 2020, 26 April 2020 / Accepted: 6 May 2020

Published online: 12 February 2021

(c) 2021 Faculty of Business and Accountancy, University of Malaya. All rights reserved.

\begin{abstract}
A B S T R A C T
Research aim: The core objective of this study is to identify the nature and extent of sustainability reporting disclosure practices among Bangladeshi listed companies, in line with global reporting initiatives (GRI).

Design/Methodology/Approach: The content analysis method is used in this study to examine a total of 48 items, consisting of 17 environmental and 31 social disclosure items, in line with GRI. Data were drawn from the published annual reports of a sample of 51 listed companies for the financial year of 2016/2017.

Research findings: On average, $13.73 \%$ of the sample companies did not disclose any issue on sustainability reporting. The overall sustainability reporting index of these companies is $10.70 \%$ (environmental: $11.42 \%$ and social: $10.31 \%$ ). The level of overall disclosure is low, with the Cement industry focusing on both social (21.18\%) and environmental (14.19\%) areas, the Textile industry mainly focusing on the environmental (17.06\%) area, and the Bank industry mainly focusing on the social $(25.16 \%)$ area. There is a paucity of disclosure of both social and environmental issues in Food \& Allied and Pharmaceuticals \& Chemicals industries. Companies are reluctant to disclose issues related to emission, effluent, waste, and compliance under the environmental dimension, and human rights and social performance indicators under the social dimension.
\end{abstract}

Theoretical contribution/ Originality: Several studies have been conducted on either corporate social reporting or environmental reporting, but there is a dearth of an integrated investigation into the level of sustainability reporting practices in Bangladesh. This study enumerates the sustainability reporting practices in Bangladesh based on the most recognised global non-financial reporting standard, namely GRI.

Practitioner/ Policy implication: With the growing awareness among stakeholders and the initiatives taken by regulators, there might be an increasing trend in sustainability reporting practices. This study is expected to contribute to the introduction of more regulatory requirements for a comprehensive framework on sustainability reporting.

Research limitation: This study focuses on only quantity and not quality in preparing the disclosure index and considers only one period.

$\overline{{ }^{1} \text { Department of Business Administration, Noakhali Science and Technology University, Noakhali 3814, Bangladesh. }}$

*email: skdas@nstu.edu.bd 
Keywords: Social Reporting, Environmental Reporting, Sustainability Reporting, Global Reporting Initiatives, Bangladesh

Type of Manuscript: Research paper

JEL Classification: M14

\section{Introduction}

Bangladesh was the seventh most affected country in terms of the Climate Risk Index (CRI), as per Global CRI 2019 (Molla, 2019). The Environmental Performance Index (EPI) 2018 ranked Bangladesh as the second-worst country in curbing environmental pollution (Environmental Performance Index, 2018). Further, in 2019, the Air Quality Index ranked Dhaka as one of the most polluted capitals in the world (Air Quality Index, 2019). As a result, the term sustainability has gained immense importance and become a burning issue in Bangladesh. Bangladesh, a developing country, is also facing environmental degradation issues due to the adverse effects of industrial activities (Ullah et al., 2013).

The concept of sustainability or sustainable development is defined as development that meets the needs of the present without compromising the ability of future generations to meet their own needs (Brundtland, 1987, p. 37). It denotes the corporate activities to sustain and enhance the ability of the organisation to create a long-term value. The activities and interrelationships among stakeholders of the organisation may have a positive or negative impact on sustainable development. At present, stakeholders demand information that portrays a holistic view of the company, encompassing financial and nonfinancial dimensions.

Due to globalisation and intense competition, companies need to meet the expectations of diverse stakeholders to sustain their business in the long term. Sustainability has taken centre stage after the United Nations declared the Millenium Development Goals (MDG) by 2000, which include ensuring environmental sustainability (goal 7 of the MDG). Moreover, Sustainable Development Goals (SDG) introduced in 2015, which are to be achieved by 2030, have several goals directly related to social and environmental issues. In developed countries, many banks have demonstrated their commitment to global sustainability by providing environmental risk financing, adopting recycling programmes, focusing on energy efficiency, purchasing carbon offsets, and sponsoring environmental events (Habib et al., 2011). Developing countries also consider these issues (Belal \& Owen, 2007; Rowe \& Guthrie, 2010), but the levels of practice are not satisfactory due to poor implementation of existing laws and policies, inadequate pressure by civil society, and a lack of incentives.

Bangladesh has formulated national-level objectives, goals, and strategic plans on environmental sustainability in order to meet the global agenda. 
Building a greener future starts today with every small green step (Hossain \& Rahman, 2013). Hence, the objective of this study is to identify the nature and extent of sustainability reporting disclosure practices by Bangladeshi firms, in line with Global Reporting Initiatives (GRI). The most comprehensive global frameworks for non-financial reporting are GRI, Accountability Standard, ISO 26000, and Integrated Reporting (Boyko \& Derun, 2016). However, this study only considers the GRI as it is the most preferred for the three pillars of sustainable development, i.e., economic, social, and environmental performance (Hohnen, 2012) and the most successful in promoting the practice of sustainability reporting, particularly among Asian and South American companies (Barkemeyer et al., 2015).

Sustainability reporting benefits organisations both internally and externally. Understanding risks and opportunities, linking financial and nonfinancial performance, and a lower cost of capital are the internal benefits of sustainability reporting. Mitigating negative social and environmental impacts, increasing branding and goodwill, and meeting the expectations of external stakeholders by focusing on the intangibles are some of the external benefits of sustainability reporting. Previous studies in the context of Bangladesh (e.g., Halder, 2015; Banerjee et al., 2017; Islam \& Ahmed, 2012) did not base their examination on the GRI standard. To fill this gap, the present study seeks to identify the nature and extent of sustainability disclosure practices by considering the GRI framework and focuses mainly on the core areas of environmental and social aspects.

This paper is structured as follows. While Section 2 focuses on the theoretical framework for sustainability reporting, Section 3 provides a discussion of the literature review. Next, Section 4 explains the research methodology and Section 5 identifies the status of sustainability reporting. Section 6 focuses on findings and analysis, and finally, Section 7 concludes the paper.

\section{The Theoretical Framework for Sustainability Reporting}

Sustainability reporting is an emerging concept across the world. It is a dynamic view of measuring a company's degree of social responsibility, economic value, and environmental impact in an integrated way by incorporating three areas of performance: social (for people), financial (for profit), and environmental (for the planet). Sustainability reporting is positively linked to a company's market value (Loh et al., 2017), expected to entice investors and analysts to provide better analyses (Aman et al., 2015), and needed to legitimise companies' position within society (Nor et al., 2016). Sustainability reporting is the consequence of companies' historical financial results; however, it goes beyond financial reporting to provide useful information to investors. 
The term sustainability reporting is also referred to as corporate social responsibility (CSR), triple bottom line (TBL), and integrated reporting (IR). CSR refers to the voluntary actions taken by a company to address the economic, social, and environmental impacts of its business operations and the concerns of its principal stakeholders (Christensen et al., 2007). TBL expresses the idea that companies or other organisations create value in multiple dimensions, i.e., economic, social, and environmental (Elkington, 2006). IR provides information about an organisation's strategy, governance, performance, and prospect in the economic, social, and environmental contexts, and it leads to the creation of value over the short, medium, and long term (International Integrated Reporting Council [IIRC], 2011, p. 2).

Today, stakeholders look at issues beyond the financial aspects in evaluating the performance and predicting the prospects of an entity (Hossain, 2017). Therefore, companies are to think about profit, people, and the planet in conducting their business. Initially, sustainability reporting was focused on the environment, but its scope has since been broadened to include ethical/social issues, employee treatment, community involvement, and the organisational structure to control all these aspects (Kolk, 2008).

Several theories can support the practice of sustainability reporting, especially by focusing on the social and environmental dimensions as a voluntary disclosure. According to agency theory, shareholders will seek to control managers' behaviour through bonding and monitoring activities. The level of disclosure is used by these two parties to mitigate information asymmetry (Healy \& Palepu, 2001). Managers will divulge social information if it enhances their welfare, as long as the benefits of this disclosure overweigh its associated costs (Ness \& Mirza, 1991). Companies that provide sustainability information will receive favourable perceptions regarding their corporate governance. According to signalling theory, companies can utilise information disclosure as a signal or mechanism that provides the market with additional information about the companies' economic reality so as to influence investor expectations and reduce information asymmetries (Baiman \& Verrecchia, 1996). Companies may also try to use disclosure to keep pace with other companies operating in the same industry.

Managers of profitable companies increase the level of disclosure to signal to investors about their companies' profitability and uphold their continuation and compensation (Oyeler et al., 2003). Based on resource dependence and stakeholder theories, companies must meet stakeholders' expectations in order to gain access to critical resources (Freeman \& Reed, 1983) and maintain the contractual relationship (Erdiaw-Kwasie et al., 2017). Legitimacy theory asserts that voluntary disclosure occurs because of public pressure. Moreover, organisations with poor environmental credentials would provide more 
extensive positive environmental disclosures in an attempt to annul the offensive activity (Cho \& Patten, 2007).

Organisations will always seek to be good corporate citizens by disclosing their activities that have favourable impacts on the environment or minimise damage to the environment, thereby demonstrating their legitimacy to stakeholders (Dawkins \& Ngunjiri, 2008). According to Lawrence Kohlberg (1981), there are three levels of moral development. At the first level, people live and act according to established social norms; at the second level, they seek approval from others through their behaviour; and at the third level, they understand the universal principle and develop autonomous decision making based on internal perspectives of right or wrong, ethics, and others, rather than any external influence. Thus, organisations decide to use corporate social reports to fulfil their obligations under the law (Boyko \& Derun, 2016). Carroll's pyramid of CSR may mirror Kohlberg's theory: organisations' fundamental responsibilities are financial (to be profitable), then legal (to obey laws and regulations), then ethical (to do what is just and fair), and finally, philanthropic (to be a good corporate citizen) (Carroll, 2016).

\section{Literature Review}

Sustainability has emerged as a pressing issue in recent years. However, most of the previous studies were conducted in the context of developed countries (Belal, 2001). After the introduction of the CSR guidelines in 2013, disclosures increased from $58.9 \%$ to $62.68 \%$ in Pakistan (Lone et al., 2016). In India, most companies disclose sustainability/CSR information in standalone reports and show a constructive change in the mode of disclosures (Jain \& Winner, 2016). The average word count in sustainability reporting has been showing an increasing trend from the year 2012 (2264 words) to 2015 (3039 words) in Sri Lanka (Dissanayake et al., 2019). Orazalin and Mahmood (2019) found that standalone reporting, reporting language, profitability, size, and auditor type influenced the nature, extent, and quality of sustainability reporting among Kazakhstani companies for the years of 2013-2015.

Several studies have been conducted on either corporate social reporting or environmental reporting, but there is a paucity of studies on the level of sustainability reporting in Bangladesh that looked at both social and environmental contexts. Disclosure of environmental-related information in annual reports was initiated in the 1970s and expanded in the 1990s (Kokubu et al., 2002). Before the 1990s, there was no specific evidence of the disclosure of environmental-related information in annual reports by any listed company on Dhaka Stock Exchange (DSE) (Shil \& Iqbal, 2005). Belal (2000) examined 30 annual reports for the year 1996 and discovered very limited environmental disclosure in those reports. A summary of past studies on voluntary disclosures is presented in Table 1. 
Table 1: Summary of prior studies in the context of Bangladesh

\begin{tabular}{|c|c|c|c|c|}
\hline Study & Sample & $\begin{array}{l}\text { Time } \\
\text { Period }\end{array}$ & Methods & Results \\
\hline $\begin{array}{l}\text { Azim, } \\
\text { Ahmed, and } \\
\text { Islam (2009) }\end{array}$ & $\begin{array}{l}263 \\
\text { companie } \\
\text { s listed on } \\
\text { the DSE }\end{array}$ & $\begin{array}{l}\text { From } \\
\text { July 1, } \\
2006 \text { and } \\
\text { June } 30 \\
2007\end{array}$ & $\begin{array}{l}\text { Content } \\
\text { analysis } \\
\text { (Empirical } \\
\text { Study) }\end{array}$ & $\begin{array}{l}\text { Only 15.45percent of listed } \\
\text { companies disclosed CSR and } \\
84.55 \text { percent having no disclosure. }\end{array}$ \\
\hline $\begin{array}{l}\text { Khan, Islam, } \\
\text { Fatima, and } \\
\text { Ahmed } \\
\text { (2011) }\end{array}$ & $\begin{array}{l}12 \\
\text { commerci } \\
\text { al banks } \\
\text { listed } \\
\text { DSE }\end{array}$ & $\begin{array}{l}2008 / 20 \\
09 \\
\text { Annual } \\
\text { reports }\end{array}$ & $\begin{array}{l}\text { Content } \\
\text { analysis } \\
\text { (Empirical } \\
\text { Study) }\end{array}$ & $\begin{array}{l}\text { Banks focused mainly on information } \\
\text { on society but rather absent in } \\
\text { reporting product responsibility and } \\
\text { human rights. }\end{array}$ \\
\hline $\begin{array}{l}\text { Saha, Dey, } \\
\text { and Khan } \\
\text { (2013) }\end{array}$ & 6 banks & $\begin{array}{l}2010 / 20 \\
11 \\
\text { Annual } \\
\text { reports }\end{array}$ & $\begin{array}{l}\text { Content } \\
\text { analysis } \\
\text { (Empirical } \\
\text { Study) }\end{array}$ & $\begin{array}{l}\text { The level of contribution by banks to } \\
\text { CSR activities was very insignificant } \\
\text { in proportion to profit. }\end{array}$ \\
\hline $\begin{array}{l}\text { Islam and } \\
\text { Ahmed } \\
(2012)\end{array}$ & $\begin{array}{l}30 \text { listed } \\
\text { banks }\end{array}$ & $\begin{array}{l}2010 / 20 \\
11 \\
\text { Annual } \\
\text { reports }\end{array}$ & $\begin{array}{l}\text { Content } \\
\text { analysis } \\
\text { (Empirical } \\
\text { Study) }\end{array}$ & $\begin{array}{l}\text { Banks disclosed information related } \\
\text { to social (42percent), employees } \\
\text { (44percent) and environmental } \\
\text { (12percent) in their annual report but } \\
\text { they did not follow any consistent } \\
\text { methods of the disclosure. }\end{array}$ \\
\hline $\begin{array}{l}\text { Belal and } \\
\text { Cooper } \\
(2011)\end{array}$ & $\begin{array}{l}23 \\
\text { companie } \\
\text { s. }\end{array}$ & - & $\begin{array}{l}23 \\
\text { interviews } \\
\text { from } \\
\text { corporate } \\
\text { seniors }\end{array}$ & $\begin{array}{l}\text { Due to lack of resources, legal } \\
\text { requirements, awareness, the profit } \\
\text { imperative, poor performance and } \\
\text { the fear of bad publicity, the key } \\
\text { areas of CSR like child labour, equal } \\
\text { opportunities, and poverty } \\
\text { alleviation were deficient. }\end{array}$ \\
\hline $\begin{array}{l}\text { Ullah, } \\
\text { Hossain, } \\
\text { and Yakub } \\
(2014)\end{array}$ & $\begin{array}{l}29 \text { listed } \\
\text { textile } \\
\text { firms }\end{array}$ & $\begin{array}{l}\text { Annual } \\
\text { reports } \\
\text { of } 2012\end{array}$ & $\begin{array}{l}\text { Content } \\
\text { analysis } \\
\text { (Empirical } \\
\text { Study) }\end{array}$ & $\begin{array}{l}\text { Two-third of the sample companies } \\
\text { did not disclose environmental issues } \\
\text { and on average disclosure was very } \\
\text { poor. }\end{array}$ \\
\hline $\begin{array}{l}\text { Nurunnabi } \\
\text { (2016) }\end{array}$ & $\begin{array}{l}71 \text { annual } \\
\text { reports }\end{array}$ & $\begin{array}{l}\text { annual } \\
\text { report of } \\
2010- \\
2011\end{array}$ & $\begin{array}{l}32 \text { semi- } \\
\text { structured } \\
\text { interviews } \\
\text { (Legitimacy } \\
\text { theory) }\end{array}$ & $\begin{array}{l}\text { On average } 2.23 \text { percent Bangladeshi } \\
\text { firms disclosed climate change } \\
\text { information in the annual report. } \\
\text { Large companies more disclosed due } \\
\text { to legitimacy reasons. Lack of } \\
\text { accountability and regulation are } \\
\text { main reasons for low disclosures. }\end{array}$ \\
\hline $\begin{array}{l}\text { Dey, Nakib } \\
\text { and Dutta } \\
\text { (2017) }\end{array}$ & $\begin{array}{l}88 \text { listed } \\
\text { companie } \\
\text { s }\end{array}$ & $\begin{array}{l}\text { Annual } \\
\text { reports } \\
\text { of } 2014\end{array}$ & $\begin{array}{l}\text { Content } \\
\text { analysis } \\
\text { (Empirical } \\
\text { Study) }\end{array}$ & $\begin{array}{l}58 \% \text { of companies reported at least } \\
\text { one issue on climate change and } \\
\text { global warming. } 4 \text { out of } 17 \\
\text { industries having no disclosures. }\end{array}$ \\
\hline Das (2017) & $\begin{array}{l}123 \\
\text { companie } \\
\text { s } 861 \text { firm } \\
\text { years }\end{array}$ & $\begin{array}{l}\text { Annual } \\
\text { reports } \\
\text { from } \\
2004 \text { to } \\
2010\end{array}$ & $\begin{array}{l}\text { Content } \\
\text { analysis and } \\
\text { regression } \\
\text { analysis } \\
\text { (Empirical } \\
\text { Study) }\end{array}$ & $\begin{array}{l}\text { The average voluntary disclosure } \\
\text { was } 28.60 \% \text { and firm sizes, liquidity, } \\
\text { percentage of independent directors } \\
\text { were motivating forces for } \\
\text { disclosures. }\end{array}$ \\
\hline
\end{tabular}


Table 1: Continued

\begin{tabular}{|c|c|c|c|c|}
\hline Study & Sample & $\begin{array}{l}\text { Time } \\
\text { Period }\end{array}$ & Methods & Results \\
\hline $\begin{array}{l}\text { Islam and } \\
\text { Chowdhury } \\
\text { (2016) }\end{array}$ & $\begin{array}{l}30 \text { listed } \\
\text { banks }\end{array}$ & $\begin{array}{l}\text { Annual } \\
\text { reports } \\
\text { from } \\
2014\end{array}$ & $\begin{array}{l}\text { Content } \\
\text { analysis } \\
\text { (Empirical } \\
\text { Study) }\end{array}$ & $\begin{array}{l}\text { In Bangladesh, the banking sector } \\
\text { disclosed general information }(66 \%) \\
\text { more than the specific aspects }(17 \%) \\
\text { and the overall disclosure level was } \\
\text { at a poor level (36\%) in terms of the } \\
\text { sustainability approach of GRI. }\end{array}$ \\
\hline $\begin{array}{l}\text { Masud, Bae, } \\
\text { and Kim } \\
(2017)\end{array}$ & $\begin{array}{l}20 \text { listed } \\
\text { banks }\end{array}$ & $\begin{array}{l}\text { Annual } \\
\text { reports } \\
\text { from } \\
2010 \text { to } \\
2014\end{array}$ & $\begin{array}{l}\text { Content } \\
\text { analysis } \\
\text { (Empirical } \\
\text { Study) }\end{array}$ & $\begin{array}{l}\text { Banks focused on the information for } \\
\text { green banking and renewable energy } \\
\text { categories while they were reluctant } \\
\text { to disclose environmental } \\
\text { recognition and waste management } \\
\text { categories and yearly comparison } \\
\text { revealed that the level of disclosure } \\
\text { increased sharply from } 16 \% \text { in } 2010 \\
\text { to } 83 \% \text { in } 2014 \text {. }\end{array}$ \\
\hline $\begin{array}{l}\text { Malik, } \\
\text { Mamun and } \\
\text { Amin (2019) }\end{array}$ & $\begin{array}{l}30 \text { listed } \\
\text { banks }\end{array}$ & $\begin{array}{l}\text { Annual } \\
\text { reports } \\
\text { from } \\
2002 \text { to } \\
2012\end{array}$ & $\begin{array}{l}\text { Content } \\
\text { analysis and } \\
\text { regression } \\
\text { analysis } \\
\text { (Empirical } \\
\text { Study) }\end{array}$ & $\begin{array}{l}\text { Competition among the banks on } \\
\text { social issues for ethical reason will } \\
\text { benefit all the stakeholders and CSR } \\
\text { spending increased both current and } \\
\text { future profitability. }\end{array}$ \\
\hline
\end{tabular}

Following the introduction of green banking by Bangladesh Bank in 2011, banks have started reporting their green banking activities, albeit inconsistencies in reporting due to the absence of standardised reporting guidelines (Hossain et al., 2016). Among the commercial banks in Bangladesh, the practice of reporting sustainability based on the GRI guidelines is also a recent phenomenon. GRI, a non-profit organisation, is the pioneer in global sustainability reporting. This independent international organisation is based in Amsterdam, the Netherlands and has been issuing GRI Sustainability Reporting Standards since its inception in 1997. GRI issues standards that lead to efficient and effective reporting by organisations.

The current sustainability reporting practices by the banking sector in Bangladesh do not consider issuing separate sustainability reports; rather, the sustainability reports are included in the annual reports (Mahmud et al., 2017). Not many companies issue the sustainability reports, and Bangladesh adopted sustainability reporting relatively late compared to other countries (Khan et al., 2011). Most of the previous studies (e.g., Azim et al., 2009; Islam \& Chowdhury, 2016; Islam \& Ahmed, 2012; Dey et al., 2017) did not cover the global standards on sustainability reporting in an integrated way based on GRI guidelines, which are to include both social and environmental issues. Therefore, the current study aims to fill this gap by identifying the nature and extent of sustainability reporting disclosure practices in line with GRI among Bangladeshi companies listed on DSE. 


\section{Research Methodology}

\subsection{Sample Selection}

There are a total of 22 sectors listed on DSE, but only five sectors are included in this study. The selected sectors are Textile, Cement, Food \& Allied, Pharmaceuticals \& Chemicals, and Bank as these industries contribute the most to the economic development of Bangladesh. Banks are leading in the disclosure of corporate social activities, social and environmental reporting, and sustainability reporting (Dissanayake et al., 2019). The rationale for selecting the manufacturing industries is that manufacturing activities gradually worsen environmental hazards such as global warming; biodiversity degradation; and air, water, soil, and marine pollutions. A total of 51 companies listed on DSE were selected for this study (Appendix 02).

\subsection{Selection of Period}

This study selected the annual reports of 51 companies listed on the Dhaka Stock Exchange (DSE) for the financial year of 2016/2017. The rationale for selecting this financial year is to ascertain the initiatives taken by listed companies in Bangladesh after the SDG declaration in 2015 by the United Nations, of which Bangladesh is a member.

\subsection{Data Sources}

This study adopted the descriptive research method and used secondary data. Published annual reports were chosen as the principal source of data because annual reports are readily available, accessible, and a popular means of communication to stakeholders.

\subsection{Content Analysis}

This study performed content analysis as it is one of the most used and effective techniques for social and environmental research (Guthrie \& Abeysekera, 2006). The sustainability reporting index was prepared based on the GRI guidelines for content analysis. GRI 3.1 was used even though GRI 4, which became effective from July 2018, is the latest version. Out of the 250 largest companies worldwide, $93 \%$ reported their sustainability performance and $82 \%$ used the GRI (Halder, 2015). The GRI framework is considered the most wideranging among the frameworks (Willis, 2003); it is widely used as an underlying framework for the coding structure for the content analysis of annual reports in both developed and developing countries' context. Out of the total of 41 items in the disclosure index, 17 items are on core environmental performance (grouped under seven themes) and another 31 contents are on core social performance (grouped under four themes). 


\subsection{Calculating the Disclosure Index Scores}

Various approaches are available for calculating the scores regarding the extent of voluntary disclosure practices by organisations. The un-weighted disclosure index was selected for this study as it considers all types of information as equally important to the average users (Saha \& Akter, 2013). This index was used to identify the nature and extent of sustainability reporting disclosure practices. If a company provided content on a sustainability reporting indicator in its annual report, it was given the score of " 1 " and " 0 " otherwise (Rouf \& Harun, 2011).

$$
T D=\sum_{i=1}^{n} d_{i}
$$

Where, $d=1$ if item di is disclosed, $0=$ if the item is not disclosed, $n=$ number of items. Then disclosure index is calculated by total disclosure in annual report to total number of items included in disclosure index.

\section{Status of Sustainability Reporting}

The history of sustainability reporting can be traced back to as early as the 1960s and 1970s in Europe, but a proactive effort was made through the Global Reporting Initiatives (GRI) in 1997 in collaboration with United Nations Environment Programme (UNEP). Denmark adopted sustainability reporting in 1996, followed by Finland in 1997 and the Netherlands and Norway in 1999 (Pramanik et al., 2008). Sustainability reporting gained momentum in the USA after the Brundtland Report was issued, with the Environmental Protection Agency and the Securities Exchange Commission pioneering its adoption. Among the Asian countries, China, Hong Kong, Indonesia, Japan, South Korea, Malaysia, the Philippines, Singapore, and Thailand encouraged sustainability disclosures. The government of Bangladesh had enacted laws regarding the environment, such as the Bangladesh Environment Conservation Act, 1995 and the Environment Conservation Rules, 1997. In addition, the Bangladeshi government had formulated the National Environment Policy and the National Environmental Management Action Plan (NEMAP) to promote sustainability practices.

However, the reporting practices of Bangladeshi listed companies are primarily governed by the Companies Act, 1994; Bangladesh Chartered Accountants Order, 1973; Securities and Exchange Commission Rules, 1987; Bank Company Act, 1991; Securities and Exchange Ordinance, 1969; Bangladesh Accounting Standards; Bangladesh Financial Reporting Standards; and the Income Tax Ordinance, 1984. All of these laws do not prescribe any mandatory periodical environmental disclosure (Ahmad, 2012). Bangladesh 
Bank, as a regulator of financial institutions, has issued comprehensive guidelines on corporate social responsibility (CSR), adopted a comprehensive green banking policy, and introduced environmental risk management (ERM) policies into the existing credit risk management procedures to protect the vulnerability to environmental degradation and to contribute to social welfare. Banks are given tax exemption on $10 \%$ of corporate income to be spent on some specific corporate social responsibility activities. Therefore, though sustainability reporting is not yet mandatory in Bangladesh, it may be adopted voluntarily by banks or any other sector in order to adopt the reporting practices that keep pace with globalisation.

Table 2 shows the sustainability reporting by organisations in different regions of the world. As per the GRI database, a total number of 49,984 reports were prepared by 12,202 organisations worldwide from 1999 to 2018. Most of the organisations and reports were from Europe (18,330 reports by 4,044 organisations), whereas the region with the fewest reports and organisations is the Oceania region (1,677 reports by 384 organisations). About $30 \%$ of the reports were published by organisations in the Asia region.

Table 2: Sustainability Reporting Organizations in the World (From 1999 to 2018*)

\begin{tabular}{llcccc}
\hline \multirow{2}{*}{$\begin{array}{l}\text { Serial } \\
\text { Number }\end{array}$} & Regions & \multicolumn{2}{c}{ Reporting organizations } & \multicolumn{2}{c}{ Published reports } \\
\cline { 2 - 5 } & & Number & Percentage & Number & Percentage \\
\hline A & Africa & 628 & 5 & 2,959 & 6 \\
C & Asia & 4,334 & 35 & 15,102 & 30 \\
D & Europe & 4,044 & 33 & 18,330 & 37 \\
E & Latin America & 1,577 & 13 & 6,426 & 13 \\
& and the & & & & \\
F & Caribbean & & & 5,490 & 11 \\
& Northern & 1,235 & 10 & & \\
& America & & & 1,677 & 3 \\
\hline Total & Oceania & 384 & 3 & 49,984 & 100 \\
\hline
\end{tabular}

Note: *Year of publication of the report, reporting year will be the preceding year

Source: http:/ / database.globalreporting.org/search/, accessed on October 14, 2018

Table 3 presents a summary of the organisations in the South Asian Association for Regional Cooperation (SAARC) countries that made sustainability reporting disclosures. The table shows that 534 organisations had prepared 1,386 reports from 1999 to 2018. However, none of the organisations is from Afghanistan, Bhutan, Maldives, or Nepal. The country with the highest number of reporting organisations is India, with a total of 400 organisations and 984 reports. In Sri Lanka, 78 organisations had published 206 reports; whereas in Pakistan, 23 organisations had published 84 reports. In the case of Bangladesh, 33 Bangladeshi companies had published 113 sustainability reports from 1999 to 2018. 
Table 3: Reporting Organizations in SAARC Countries (From 1999 to 2018*)

\begin{tabular}{llcccc}
\hline Serial & Regions & \multicolumn{2}{c}{ Reporting organizations } & \multicolumn{2}{c}{ Published reports } \\
\cline { 2 - 6 } Number & & Number & Percentage & Number & Percentage \\
\hline A & Afghanistan & 0 & 0 & 0 & 0 \\
B & Bangladesh & 33 & 6 & 113 & 8 \\
C & Bhutan & 0 & 0 & 0 & 0 \\
D & India & 400 & 75 & 984 & 71 \\
E & Maldives & 0 & 0 & 0 & 0 \\
F & Nepal & 0 & 0 & 0 & 0 \\
G & Pakistan & 23 & 4 & 84 & 6 \\
H & Sri Lanka & 78 & 15 & 206 & 15 \\
\hline & Total & 534 & 100 & 1,386 & 100 \\
\hline
\end{tabular}

Note: *Year of publication of the report, reporting year will be the preceding year

Source: http:/ / database.globalreporting.org/search/, accessed on October 14, 2018

Table 4 portrays the status of sustainability organisations in the SAARC countries in only the year of 2018. A total of 25 reports were published by 24 Indian organisations, two reports by two Pakistani organisations, six reports by eight Sri Lankan organisations, and seven reports by seven Bangladeshi organisations, as shown on the GRI website. During the year of 2018, a total 567 sustainability reports was published by 565 organisations while only $7 \%$ was contributed by SAARC.

Table 4: Sustainability Reporting Organizations in SAARC Countries (Only in 2018*)

\begin{tabular}{llcccc}
\hline \multirow{2}{*}{$\begin{array}{l}\text { Serial } \\
\text { Number }\end{array}$} & Regions & \multicolumn{2}{c}{ Reporting organizations } & \multicolumn{2}{c}{ Published reports } \\
\cline { 2 - 6 } & & Number & Percentage & Number & Percentage \\
\hline A & Afghanistan & 0 & 0 & 0 & 0 \\
B & Bangladesh & 7 & 18 & 7 & 18 \\
$\mathrm{C}$ & Bhutan & 0 & 0 & 0 & 0 \\
$\mathrm{D}$ & India & 24 & 62 & 25 & 63 \\
$\mathrm{E}$ & Maldives & 0 & 0 & 0 & 0 \\
$\mathrm{~F}$ & Nepal & 0 & 0 & 0 & 0 \\
$\mathrm{G}$ & Pakistan & 2 & 5 & 2 & 5 \\
$\mathrm{H}$ & Sri Lanka & 8 & 21 & 6 & 15 \\
\hline Total in SAARC & 39 & $7 \%$ of Asia & 40 & $7 \%$ of Asia \\
Total in Asia & 565 & $38 \%$ of Global & 567 & $38 \%$ of Global \\
\multicolumn{2}{l}{ Total around the world } & 1,483 & & 1,491 & \\
\hline
\end{tabular}

Note: *Year of publication of the report, reporting year will be the preceding year

Source: http://database.globalreporting.org/search/, accessed on October 14, 2018

\section{Analysis and Findings}

This section mainly focuses on the existing disclosures practices by Bangladeshi companies in their annual reports. Figure- 1 exhibits that $86.27 \%$ of the selected Bangladeshi companies made sustainability reporting disclosures in at least one item or category in their annual reports and the remaining $13.73 \%$ did not make any sustainability reporting disclosure. Moreover, most of the companies 
in the Bank and Cement sectors made sustainability reporting disclosures in their annual reports or sustainability reports in accordance with GRI guidelines. However, seven companies, consisting of one company from the Textile industry, three companies from the Pharmaceuticals \& Chemicals industry, and three companies from the Food \& Allied industry failed to provide sustainability reporting information.

On specific disclosures related to the environment, Figure 1 shows that $76.47 \%$ of the sampled companies disclosed at least one environmental-related item or category. The remaining $23.53 \%$ that did not make such disclosure consisted of 12 manufacturing firms, of which two were from the Textile industry, seven were from the Pharmaceuticals \& Chemicals industry, and three were from the Food \& Allied industry. On social-related disclosure, $70.59 \%$ of the sampled companies disclosed at least one item or category on the social aspect, but $29.41 \%$ of the companies failed to do so. The companies that did not make such disclosure consisted of 15 manufacturing firms, of which eight were from the Textile industry, four were from the Pharmaceuticals \& Chemicals industry, and three were from the Food \& Allied industry.

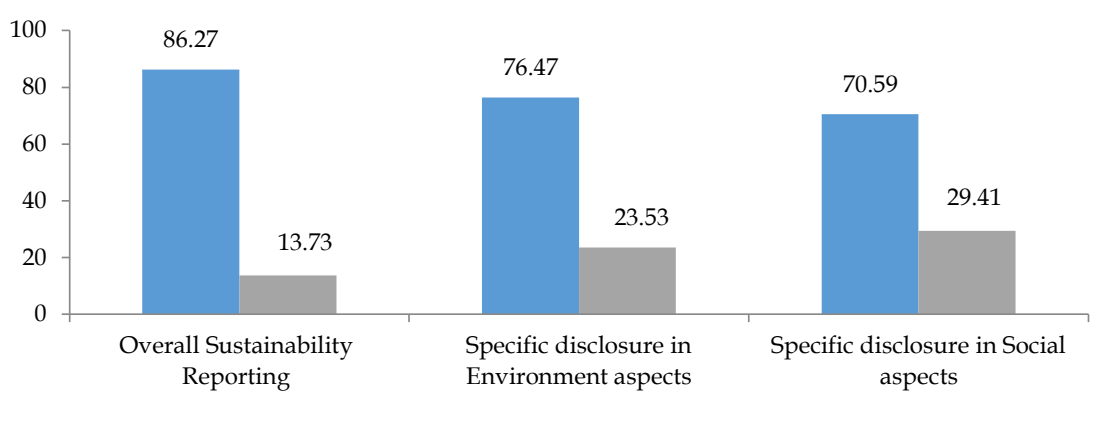

nCompanies with disclosures in at least one content $\quad$ Companies with no disclosure

Figure 1: Overall Sustainability Reporting Disclosures by the Bangladeshi companies Source: Analyzed by the Authors

Table 5 shows that the overall sustainability reporting index for the companies is $10.70 \%$ ( $11.42 \%$ for environmental disclosure and $10.31 \%$ for social disclosure). Figures 2 and 3 show that the sustainability reporting indexes of Textile, Cement, Food \& Allied, Pharmaceuticals \& Chemicals, and Bank sectors are $9.38 \%, 16.67 \%, 3.82 \%, 5.42 \%$, and $19.79 \%$, respectively. The Cement industry made disclosures for both social (21.18\%) and environmental $(14.19 \%)$ areas, but the Textile industry mainly disclosed on the environmental aspect $(17.06 \%)$ while the Bank industry mainly disclosed on the social aspect $(25.16 \%)$. Overall, the level of disclosure is low, with inadequate disclosures on 
both social and environmental aspects in Food \& Allied as well as Pharmaceuticals \& Chemicals industries. Within the Bank industry, Bank Asia Limited, Mutual Trust Bank Ltd., Eastern Bank Limited, and Prime Bank Limited mentioning GRI standard in their annual sustainability reports, but BRAC Bank Limited and South East Bank did not cite GRI.

Table 5: Overall disclosure index on environmental and social aspects

\begin{tabular}{llll}
\hline $\begin{array}{l}\text { Performance } \\
\text { Indicator }\end{array}$ & $\begin{array}{l}\text { Required } \\
\text { Disclosure }\end{array}$ & Actual Disclosure & Disclosure Index \\
\hline Environment & 867 & 99 & $11.42 \%$ \\
Social & 1581 & 163 & $10.31 \%$ \\
Total & 2448 & 262 & $10.70 \%$ \\
\hline
\end{tabular}

Source: Compiled by authors

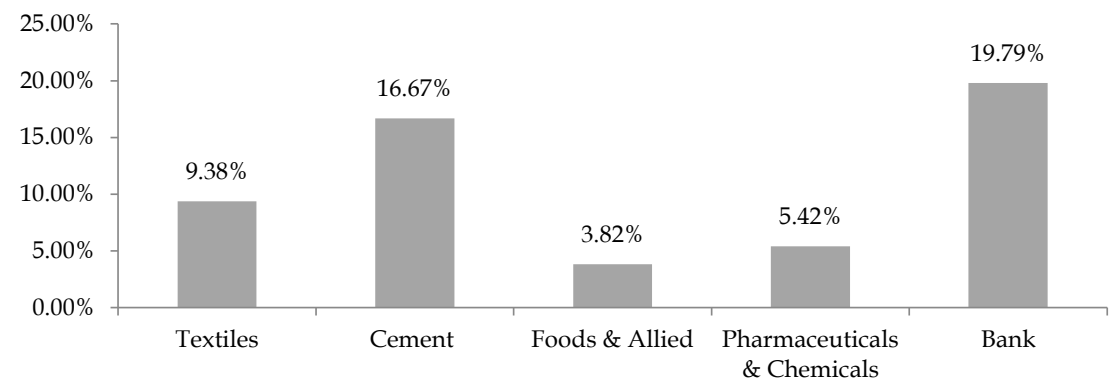

घverall SR disclosure practices by industries

Figure 2: Overall SR disclosure practices by industries Source: Compiled by authors

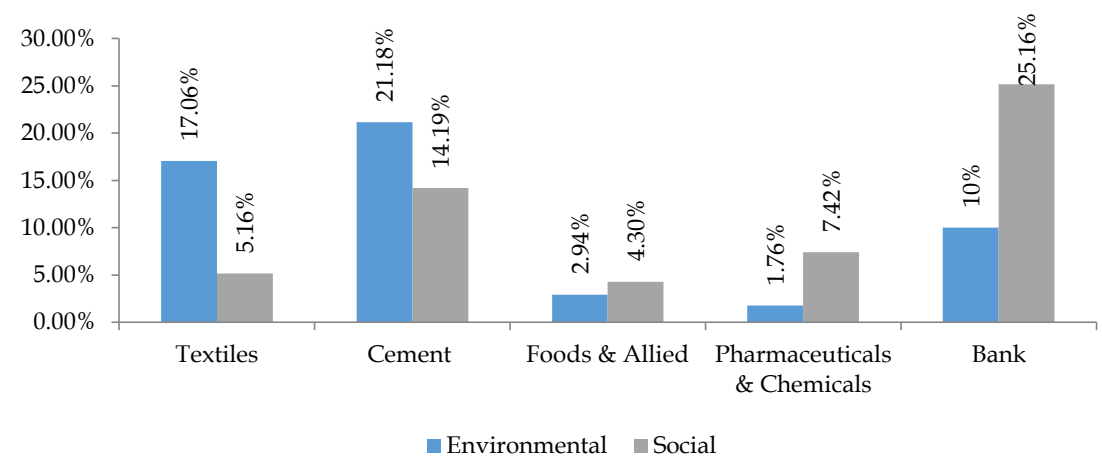

Figure 3: Percentage of industry wise disclosure of environmental and social aspects. Source: Compiled by authors 
Table 6 and Fig. 4 show the disclosures for the main themes under the environmental dimension: Material (24.5\%), Energy (19.6\%), Water (13.73\%), Biodiversity (28.43\%), Emissions, Effluents and Waste $(1.68 \%)$, Products and Service $(11.76 \%)$, and Compliance $(0 \%)$. Companies are reluctant to disclose issues related to emission, effluent, and waste, as well as compliance. The disclosure on Material is dominated by Textile and Cement industries; Energy is dominated by Textile, Cement, and Bank industries; Water is dominated by the Textile industry; and Biodiversity and Product and Services are dominated by Cement and Bank industries. However, the Emissions, Effluents, and Waste theme and the Compliance theme are ignored. Overall, the environmental disclosure is not satisfactory even though companies from Textile and Cement industries disclosed some of the environmental aspects.

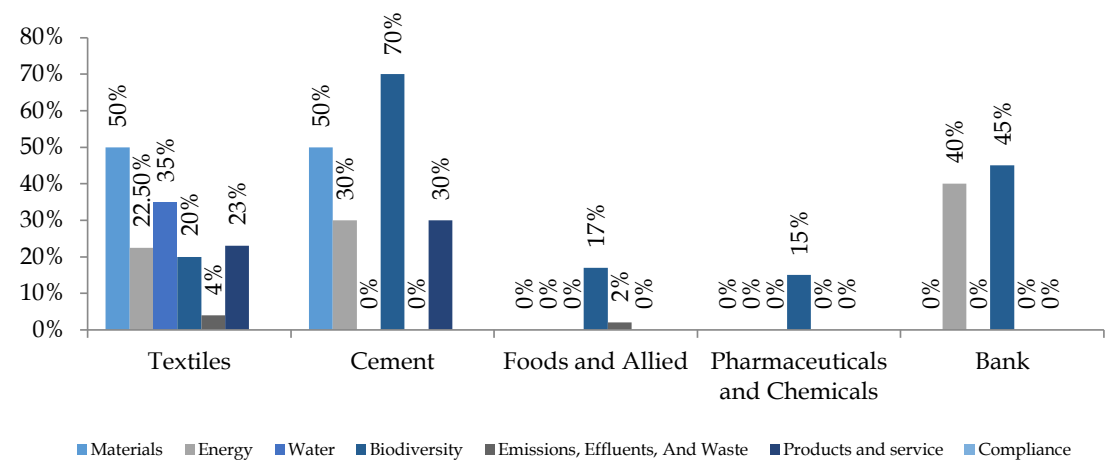

Figure 4: Specific disclosures on Environment aspects by Industry Source: Compiled by authors

Table 6: Overall specific disclosures on Environment aspects

\begin{tabular}{llll}
\hline Themes & $\begin{array}{l}\text { Required } \\
\text { disclosures }\end{array}$ & $\begin{array}{l}\text { Actual } \\
\text { Disclosures }\end{array}$ & $\begin{array}{l}\text { Disclosures } \\
\text { Index }\end{array}$ \\
\hline Materials & 102 & 25 & $24.51 \%$ \\
Energy & 102 & 20 & $19.61 \%$ \\
Water & 51 & 7 & $13.73 \%$ \\
$\begin{array}{l}\text { Biodiversity } \\
\text { Emissions, Effluents, and }\end{array}$ & 102 & 29 & $28.43 \%$ \\
$\begin{array}{l}\text { Waste } \\
\text { Products and service }\end{array}$ & 357 & 6 & $1.68 \%$ \\
Compliance & 102 & 12 & $11.76 \%$ \\
\hline
\end{tabular}

Source: Compiled by authors

Table 7 and Fig. 5 depict the disclosures by companies according to the themes under the social dimension: Labour Practices and Decent Work (17.84\%), Human Rights (4.58\%), Society (5.15\%), and Product Responsibility 
(15.20\%). Companies seem reluctant to disclose the human rights and social performance indicators under the social dimension, with disclosure on the Human Rights theme scoring the lowest. Meanwhile, Labour Practices, Society, and Product Responsibility themes are dominated by Bank and Cement industries. In this study, it is apparent that Textile, Food \& Allied, and Pharmaceuticals \& Chemicals industries are very reluctant to disclose information on social performance indicators.

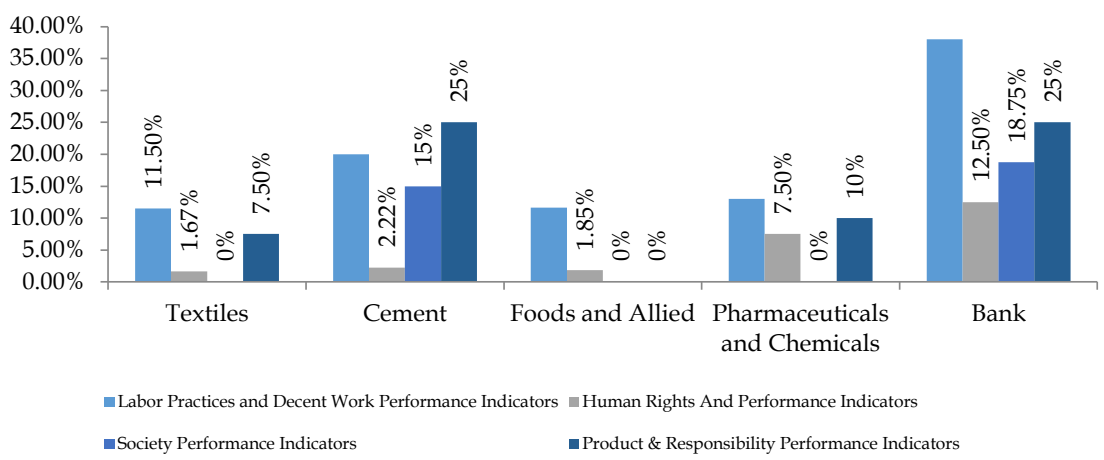

Figure 5: Specific disclosures on Social aspects by Industry Source: Compiled by authors

Table 7: Overall specific disclosures on social aspects

\begin{tabular}{lccc}
\hline Theme & $\begin{array}{c}\text { Required } \\
\text { Disclosure }\end{array}$ & $\begin{array}{c}\text { Actual } \\
\text { Disclosure }\end{array}$ & $\begin{array}{c}\text { Overall Social } \\
\text { aspects } \\
17.84 \%\end{array}$ \\
$\begin{array}{l}\text { Labour Practices and Decent Work } \\
\text { Performance Indicators }\end{array}$ & 510 & 91 & $4.58 \%$ \\
$\begin{array}{l}\text { Human Rights and Performance } \\
\begin{array}{l}\text { Indicators } \\
\text { Society Performance Indicators }\end{array}\end{array}$ & 459 & 21 & $5.15 \%$ \\
$\begin{array}{l}\text { Product and Responsibility } \\
\text { Performance Indicators }\end{array}$ & 408 & 21 & $15.20 \%$ \\
\hline S & 204 & 31 & \\
\hline
\end{tabular}

Source: Compiled by authors

Table 8: The level of disclosure level in terms of the number of Company

\begin{tabular}{ll}
\hline Level of disclosure & No. of companies \\
\hline Less than $10 \%$ & 27 \\
$10 \%-20 \%$ & 17 \\
$20 \%-30 \%$ & 6 \\
$30 \%-40 \%$ & 1 \\
$40 \%-50 \%$ & 0 \\
More than $50 \%$ & 0 \\
\hline
\end{tabular}


Table 8 depicts the ranges of disclosure of the 51 sampled companies. A total of 27 companies disclosed less than $10 \%$ of the disclosed items, 17 companies disclosed in the range of 10-20\%, while one company disclosed in the range of $30-40 \%$. Only 6 companies disclosed in between the range of $20-30 \%$. Therefore, the overall social and environmental disclosure is very low.

Under the environmental dimension, Material and Biodiversity attained the highest levels of disclosure, whereas the least disclosed items are under the Emissions, Effluents, and Waste theme and the Compliance theme. Under the social dimension, most of the disclosures are for Labour Practices and Decent Work as well as Product Responsibility themes, whereas Human Rights and Society themes were the least disclosed by the companies. Companies from Bank and Cement industries made some effort to disclose voluntary information in their corporate annual reports, but companies from Textile, Pharmaceuticals \& Chemicals, and Food \& Allied industries lagged in social and environmental reporting. The main reasons for nondisclosure are an inadequate legal framework, a lack of stakeholder awareness, the costs outweigh the benefits, attitude for secrecy, poor performance, nonconsideration of performance measurement, and fear of bad publicity (Belal, 2007; Rowe, 2007). An absence of credible external verification and a lack of measurement consistency in social and environmental reporting systems are also major limitations for the preparation of a standard social and environmental report. The low level of disclosure can also be attributed to a very low level of social accountability among the companies. However, nowadays, large companies tend to disclose more voluntary information in their annual reports to legitimise their position in the market. The government and other relevant regulatory authorities should take necessary steps to compel, motivate, and reward all companies in Bangladesh to address social and environmental issues in their annual corporate reports. Moreover, manufacturing companies in Bangladesh should have specific disclosure policy regarding environmentally related issues in a standard and comprehensive format to ensure their sustainability in this competitive age. This standard should raise the bar of disclosure but leave enough space for additional voluntary reporting aligned with the global standards in the context of a globalised economy in order to improve comparability and consistency, avoid duplication, and ensure that goals from international agreements are attained.

\section{Conclusion}

Sustainability reporting is a growing concept during this information age. This study scrutinised the nature and extent of Bangladeshi companies' sustainability reporting practices based on the GRI standard. The study finds that sustainability reporting practices in Bangladesh are still at the infancy stage and mostly voluntary. On average, $86.27 \%$ of the selected Bangladeshi 
companies disclosed sustainability reporting issues for at least one item in their annual reports. About $23.53 \%$ of the sampled companies did not disclose at least one item in the environmental aspect and $29.41 \%$ the sampled companies did not disclose at least one item in the social aspect at all.

The overall sustainability reporting index of the companies is $10.70 \%$. The Cement industry made both social and environmental disclosures, but the Textile industry mainly focused on the environmental aspect only while the Banks mainly focused on the social aspect. There is a paucity of disclosure in both social and environmental aspects among Food \& Allied as well as Pharmaceuticals \& Chemicals industries. The sampled companies did not focus on Emissions, Effluents, and Waste and Compliance under the environmental dimension and Human Rights and Social Performance under the social dimension. Thus, it can be said that the extent of disclosure among the sampled companies is not satisfactory.

Social and environmental disclosures are not mandatory in Bangladesh, but they form part of the financial statements, which are included in the annual reports. With the increasing awareness among stakeholders and the initiatives taken by regulators, sustainability reporting practices are showing an increasing trend. This study is expected to contribute to the introduction of more regulatory requirements for a comprehensive reporting framework and encourage an increasing trend for disclosure practices.

The government, regulatory bodies, and organisations established for environmental protection are expected to realise the current social and environmental disclosure practices by manufacturing companies and to formulate appropriate guidelines and laws. Hence, an understanding of the needs and interests of different stakeholder groups will ensure that corporate reporting will meet those needs. Statutory disclosure of social and environmental information has been implemented in both developed and developing nations. The Financial Reporting Council of Bangladesh, Bangladesh Securities and Exchange Commission (BSEC), and Dhaka Stock Exchange (DSE) should mandate companies to establish an environmental, social, health, and safety committee to promote sustainable development and general corporate social responsibility. To be a good corporate citizen and to sustain in their business in the long run, every company should disclose sustainability issues in their reporting. This study focused on quantity rather than quality in preparing the disclosure index and considered data for only one year; hence, the findings might be different over the years.

\section{References}

Ahmad, A. (2012). Environmental Accounting and reporting practices: significance and issues: A case from Bangladeshi Companies. Global Journal of Management and Business Research, 12(14), 119-127. 
Air Quality Index (2019, November 25). Dhaka again ranks worst in Air Quality Index. Dhaka Tribune. $\quad$ https://www.dhakatribune.com/bangladesh/dhaka/2019/11/25/dhakaagain-ranks-worst-in-air-quality-index

Aman, Z., Ismail, S., \& Bakar, N. S. (2015, November 16-17). Corporate sustainability reporting: Malaysian evidence. Proceeding of the 2nd International Conference on Management and Muamalah 2015 (2ndICoMM), Selangor, Malaysia. http://conference.kuis.edu.my/icomm/2nd/download/IC\%20025.pdf

Azim, M. I., Ahmed, S., \& Islam, M. S. (2009). Corporate social reporting practice: evidence from listed companies in Bangladesh. Journal of Asia-Pacific Business, 10(2), 130-145. https://doi.org/10.1080/10599230902885556

Baiman, S., \& Verrecchia, R. E. (1996). The relation among capital markets, financial disclosure, production efficiency, and insider trading. Journal of Accounting Research, 34(1), 1-22. https:// doi.org/10.2307/2491329

Banerjee, P. K., Mustafa, M. S., Hossain, M. M., \& Ahmed, I. (2017). Sustainability Reporting Practices in Banks of Bangladesh, Research Monograph, No. 31, Bangladesh Institute of Bank Management, Dhaka, Bangladesh.

Barkemeyer, R., Preuss, L., \& Lee, L. (2015). On the effectiveness of private transnational governance regimes-Evaluating corporate sustainability reporting according to the Global Reporting Initiative. Journal of World Business, 50(2), 312-325. https://10.1016/j.jwb.2014.10.008

Belal A. R. (2007). Absence of corporate social reporting (CSR) in Bangladesh: A research note. Presented in the in the 'Research Workshop' at the Aston Business School. https://www.researchgate.net/publication/40498896_Absence_of_corporate_social_rep orting_CSR_in_Bangladesh_a_research_note

Belal, A. R. (2000). Environmental reporting in developing countries: empirical evidence from Bangladesh. Eco-Management and Auditing: The Journal of Corporate Environmental Management, 7(3), 114-121. https://doi.org/10.1002/1099-0925(200009)7:3<114::AIDEMA131>3.0.CO;2-E

Belal, A. R. (2001). A study of corporate social disclosures in Bangladesh. Managerial Auditing Journal, 16(5), 274-289. https://doi.org/10.1108/02686900110392922

Belal, A. R., \& Cooper, S. (2011). The absence of corporate social responsibility reporting in Bangladesh. Critical Perspectives on Accounting, 22(7), 654-667. https://doi.org/10.1016/j.cpa.2010.06.020

Belal, A. R., \& Owen, D. (2007). The views of corporate managers on the current state of, and future prospects for, social reporting in Bangladesh. Accounting, Auditing and Accountability Journal, 20(3), 472-494. https:// doi.org/10.1108/09513570710748599

Boyko, K., \& Derun, I. (2016). Disclosure of non-financial information in corporate social reporting as a strategy for improving management effectiveness. Journal of International Studies, 9(3), 159-177. https:/ / doi.org/10.14254/2071-8330.2016/9-3/13

Brundtland, G. H. (1987). Report of the World Commission on Environment and Development: Our Common Future. Oxford University Press. https://sustainabledevelopment.un.org/content/documents/5987our-commonfuture.pdf

Carroll, A. B. (2016). Carroll's pyramid of CSR: taking another look. International Journal of Corporate Social Responsibility, 1(1), 3. https:/ / doi.org/10.1186/s40991-016-0004-6

Cho, C. H., \& Patten, D. M. (2007). The role of environmental disclosures as tools of legitimacy: A research note. Accounting, Organizations and Society, 32(7-8), 639-647. https://doi.org/10.1016/j.aos.2006.09.009

Christensen, L., Peirce, E., Hartman, L., Hoffman, W., \& Carrier, J. (2007). Ethics, CSR, and Sustainability Education in the Financial Times Top 50 Global Business Schools: Baseline 
Data and Future Research Directions. Journal of Business Ethics, 73(4), 347-368. https://10.1007/s10551-006-9211-5.

Das, S. (2017). The impact of corporate attributes on the extent of voluntary disclosure and reporting by listed companies in Bangladesh. International Journal of Accounting and Business Finance, 3(1), 12-45. Retrieved from http://www.maco.jfn.ac.lk/ijabf/wpcontent/uploads/2017/11/vol3_issue1_2.pdf.

Dawkins, C., \& Ngunjiri, F. W. (2008). Corporate social responsibility reporting in South Africa: A descriptive and comparative analysis. The Journal of Business Communication (1973), 45(3), 286-307. https:// doi.org/10.1177\%2F0021943608317111

Dey, P. K., Nakib, M., \& Dutta, P. (2017). Climate Change Disclosures in the Annual Reports: Evidence from Bangladesh. Asian Journal of Finance and Accounting, 9(2), 88-102. https:// doi.org/10.5296/ajfa.v9i2.11736

Dissanayake, D., Tilt, C., \& Qian, W. (2019). Factors influencing sustainability reporting by Sri Lankan companies. Pacific Accounting Review, 31(1), 84-109. https://10.1108/PAR-102017-0085

Elkington, J. (2006). Governance for sustainability. Corporate Governance: An International Review, 14(6), 522-529. https:// doi.org/10.1111/j.1467-8683.2006.00527.x

Environmental Performance Index. (2018). Environmental Performance Index Results. Yale Center for Environmental Law \& Policy, Center for International Earth Science Information Network Earth Institute, Columbia University, The McCall MacBain, Foundation. https://epi.yale.edu/epi-indicator-report/EPI

Erdiaw-Kwasie, M., Alam, K., \& Shahiduzzaman, M. (2015). Towards Understanding Stakeholder Salience Transition and Relational Approach to 'Better' Corporate Social Responsibility: A Case for a Proposed Model in Practice. Journal of Business Ethics, 144(1), 85-101. https://doi.org/10.1007/s10551-015-2805-z

Freeman, R., \& Reed, D. (1983). Stockholders and Stakeholders: A New Perspective on Corporate Governance. California Management Review, 25(3), 88-106. https:// doi.org/10.2307/41165018

Guthrie, J., \& Abeysekera, I. (2006). Content analysis of social, environmental reporting: what is new? Journal of Human Resource Costing and Accounting, 10(2), 114-126. https:// doi.org/10.1108/14013380610703120

Habib, S. M. A., Ullah, M. S., \& Rahman, T. (2011). An Impact Evaluation of Green Initiatives of Bangladesh Bank, Banking Research Series 2011, BIBM, Dhaka.

Halder (2015). Sustainability Reporting and Integrated Reporting. The Cost and Management, 43(5), 51.

Healy, P., \& Palepu, K. (2001). Information Asymmetry, Corporate Disclosure and the Capital Markets: A Review of the Empirical Disclosure Literature. Journal of Accounting and Economics, 31(1-3), 405-440. https:// doi.org/10.2139/ssrn.258514

Hohnen, P. (2012). The future of sustainability reporting. EEDP Programme Paper. Chatham House, London.

Hossain, D. M., Bir, A., Sadiq, A. T., Tarique, K. M., \& Momen, A. (2016). Disclosure of green banking issues in the annual reports: a study on Bangladeshi banks. Middle East Journal of Business, 11(1), 19-30. https:// doi.org/10.5742/mejb.2015.92758

Hossain, M. M. (2017). Sustainability Report of Financial Services Industry in SAARC Countries: Special Reference to Bangladesh. Independent Business Review, 10(1/2), 144-192.

Hossain, M. M. \& Rahman, T. (2013). Green Annual Report of Banks in Bangladesh: Issues and Challenges. Journal of the Institute of Bankers Bangladesh, 60(2), 11-40. https://doi.org/10.1108/cg-05-2016-0100 
Islam, M., \& Chowdhury, M. (2016). Corporate sustainability reporting in the banking sector of Bangladesh: an appraisal of the G4 of the Global Reporting Initiative. International Journal of Green Economics, 10(3/4), 252-278. https:/ / doi.org/10.1504/ijge.2016.10002859

Islam, N., \& Ahmed, T. (2012). Corporate social and environmental disclosure-an econometric analysis of listed private commercial banks in Bangladesh. Indian Journal of Commerce and Management, 3(3), 59-65.

Jain, R., \& Winner, L. H. (2016). CSR and sustainability reporting practices of top companies in India. Corporate Communications: An International Journal, 21(1), 36-55. https://doi.org/10.1108/CCIJ-09-2014-0061

Khan, H., Azizul Islam, M., Kayeser Fatima, J., \& Ahmed, K. (2011). Corporate sustainability reporting of major commercial banks in line with GRI: Bangladesh evidence. Social Responsibility Journal, 7(3), 347-362. https:/ / doi.org/10.1108/17471111111154509

Kohlberg, L. (1981). Essays in moral development: The philosophy of moral development. New York: Harper Row.

Kokubu, A. N., Onishi, Y., Shinabe, T., \& Nigashida, A. (2002). An Examination of Corporate Disclosure on Environmental Report Publication and its Quality in Japanese Companies. Kobe University, Japan.

Kolk, A. (2008). Sustainability, accountability and corporate governance: exploring multinationals' reporting practices. Business Strategy and the Environment, 17(1), 1-15. https://doi.org/10.1002/bse.511

Loh, L., Thomas, T., and Wang, Y. (2017). Sustainability reporting and firm value: Evidence $\begin{array}{llll}\text { from Singapore-listed } & \text { companies. }\end{array}$ https://doi.org/10.3390/su9112112

Lone, E. J., Ali, A., \& Khan, I. (2016). Corporate governance and corporate social responsibility disclosure: evidence from Pakistan. Corporate Governance: The International Journal of Business in Society, 16(5), 785-797. https:/ / doi.org/10.1108/CG-05-2016-0100

Mahmud, S., Biswas, T., \& Islam, N. (2017). Sustainability Reporting Practices and Implications of Banking Sector of Bangladesh according to Global Reporting Initiative (GRI) Reporting Framework: An Empirical Evaluation. International Journal of Business and Management Invention, 6(3), 01-14.

Malik, M., Al Mamun, M., \& Amin, A. (2018). Peer pressure, CSR spending, and long-term financial performance. Asia-Pacific Journal of Accounting and Economics, 26(3), 241-260. https://doi.org/10.1080/16081625.2018.1493933

Masud, M., Bae, S., \& Kim, J. (2017). Analysis of environmental accounting and reporting practices of listed banking companies in Bangladesh. Sustainability, 9(10), 1717. https://doi.org/10.3390/su9101717

Molla, M. (2019, December 5). Extreme Weather Events: Bangladesh 7th worst-hit nation. The Daily Star, p. 16. https://www.thedailystar.net/backpage/news/climate-changebangladesh-7th-worst-hit-nation-1835905

Ness, K., \& Mirza, A. (1991). Corporate social disclosure: A note on a test of agency theory. The British Accounting Review, 23(3), 211-217. https://doi.org/10.1016/0890-8389(91)90081-c

Nor, N., Bahari, N., Adnan, N., Kamal, S., \& Ali, I. (2016). The Effects of Environmental Disclosure on Financial Performance in Malaysia. Procedia Economics and Finance, 35, 117126. https:// doi.org/10.1016/s2212-5671(16)00016-2

Nurunnabi, M. (2016). Who cares about climate change reporting in developing countries? The market response to, and corporate accountability for, climate change in Bangladesh. Environment, Development and Sustainability, 18(1), 157-186. https://doi.org/10.1007/s10668-015-9632-3 
Orazalin, N., \& Mahmood, M. (2019). Determinants of GRI-based sustainability reporting: evidence from an emerging economy. Journal of Accounting in Emerging Economies, 10(1), 140-164. https:/ / doi.org/10.1108/jaee-12-2018-0137

Oyelere, P., Laswad, F., \& Fisher, R. (2003). Determinants of Internet Financial Reporting by New Zealand Companies. Journal of International Financial Management and Accounting, 14(1), 26-63. https:// doi.org/10.1111/1467-646x.00089

Pramanik, A., Shil, N., \& Das, B. (2008). Corporate Environmental Reporting: An Emerging Issue in the Corporate World. International Journal of Business and Management, 3(12), 146154. https://doi.org/10.5539/ijbm.v3n12p146

Rouf, M. A. \& Harun M. A. (2011). Ownership structure and voluntary disclosures in annual reports of Bangladesh. Pakistan Journal of Commerce and Social Science, 5(1), 129-139. Retrieved from: http://jespk.net/paper.php?paperid=49

Rowe, A. L. (2007, July 8-10). Corporate environmental reporting: informal institutional Chinese cultural norms. 5th Asian Pacific Interdisciplinary Research in Accounting (APIRA) Conference, Auckland, New Zealand.

Rowe, A., \& Guthrie, J. (2010). The Chinese Government's Formal Institutional Influence on Corporate Environmental Management. Public Management Review, 12(4), 511-529. https:// doi.org/10.1080/14719037.2010.496265

Saha, A. K., Dey, S., \& Khan, A. (2013). Corporate social responsibility in Bangladesh: A Comparative study of Commercial Banks of Bangladesh. The Bangladesh Accountant, 69-80.

Shil, N. C., \& Iqbal M., (2005). Environmental Disclosure-A Bangladesh Perspective, The Cost and Management, 3, 85-93.

Ullah, M. H., Hossain, M. M., \& Yakub, K. M. (2014). Environmental Disclosure Practices in Annual Report of the Listed Textile Industries in Bangladesh. Global Journal of Management and Business Research, 14(1), 97-108.

Ullah, M. H., Yakub, K. M., \& Hossain, M. H. (2013). Environmental reporting practices in annual report of selected listed companies in Bangladesh. Research Journal of Finance and Accounting, 4(7), 45-58.

Willis, C. A. (2003). The Role of the Global Reporting Initiative's Sustainability Reporting Guidelines in the Social Screening of Investments. Journal of Business Ethics, 43(3), 233-237. https://doi.org/10.1023/A:1022958618391 


\section{Appendices}

Appendix 1: Sustainability indictors derived from GRI standard for content analysis.

\begin{tabular}{|c|c|c|}
\hline \multicolumn{2}{|c|}{ Indicators } & \multirow[t]{2}{*}{ Code } \\
\hline 1 & Environment: Performance Indicators & \\
\hline & Aspect: Materials & \\
\hline & Materials used by weight or volume (EN1) & EN1 \\
\hline & Percentage of materials used that are recycled input materials. & EN2 \\
\hline \multirow[t]{3}{*}{2} & Aspect: Energy & \\
\hline & Direct energy consumption by primary energy source. & EN3 \\
\hline & Indirect energy consumption by primary source & EN4 \\
\hline \multirow[t]{3}{*}{3} & Aspect: Water & \\
\hline & Total water withdrawal by source. & EN8 \\
\hline & Aspect: Biodiversity & \\
\hline \multirow{2}{*}{4} & $\begin{array}{l}\text { Location and size of land owned, leased, managed in, or adjacent to, } \\
\text { protected areas and areas of high biodiversity value outside protected } \\
\text { areas. }\end{array}$ & EN11 \\
\hline & $\begin{array}{l}\text { Description of significant impacts of activities, products, and services on } \\
\text { biodiversity in protected areas and areas of high biodiversity value outside } \\
\text { protected areas. }\end{array}$ & EN12 \\
\hline \multirow[t]{8}{*}{5} & Aspect: Emissions, Effluents, and Waste & \\
\hline & Total direct and indirect greenhouse gas emissions by weight. & EN16 \\
\hline & Other relevant indirect greenhouse gas emissions by weight. & EN17 \\
\hline & Emissions of ozone-depleting substances by weight. & EN19 \\
\hline & $\mathrm{NO}, \mathrm{SO}$, and other significant air emissions by type and weight. & EN20 \\
\hline & Total water discharge by quality and destination & EN21 \\
\hline & Total weight of waste by type and disposal method & EN22 \\
\hline & Total number and volume of significant spills. & EN23 \\
\hline \multirow[t]{3}{*}{6} & Aspect: Products and Services & \\
\hline & $\begin{array}{l}\text { Initiatives to mitigate environmental impacts of products and services, and } \\
\text { extent of impact mitigation. }\end{array}$ & EN26 \\
\hline & $\begin{array}{l}\text { Percentage of products sold and their packaging materials that are } \\
\text { reclaimed by category. }\end{array}$ & EN27 \\
\hline \multirow[t]{2}{*}{7} & Aspect: Compliance & \\
\hline & $\begin{array}{l}\text { Monetary value of significant fines and total number of non-monetary } \\
\text { sanctions for non-compliance with environmental laws and regulations }\end{array}$ & EN28 \\
\hline \multirow[t]{9}{*}{1} & Social Performance Indicators & \\
\hline & Labour Practices and Decent Work Performance Indicators & \\
\hline & Aspect: Employment & \\
\hline & $\begin{array}{l}\text { Total workforce by employment type, employment contract, and region, } \\
\text { broken down by gender. }\end{array}$ & LA1 \\
\hline & $\begin{array}{l}\text { Total number and rate of new employee hires and employee turnover by } \\
\text { age group, gender, and region. }\end{array}$ & LA3 \\
\hline & $\begin{array}{l}\text { Return to work and retention rates after parental leave, by gender. } \\
\text { Aspect: Labour/Management Relations }\end{array}$ & LA15 \\
\hline & Percentage of employees covered by collective bargaining agreements. & LA4 \\
\hline & $\begin{array}{l}\text { Minimum notice period(s) regarding operational changes, including } \\
\text { whether it is specified in collective agreements. }\end{array}$ & LA5 \\
\hline & Aspect: Occupational Health and Safety & \\
\hline
\end{tabular}




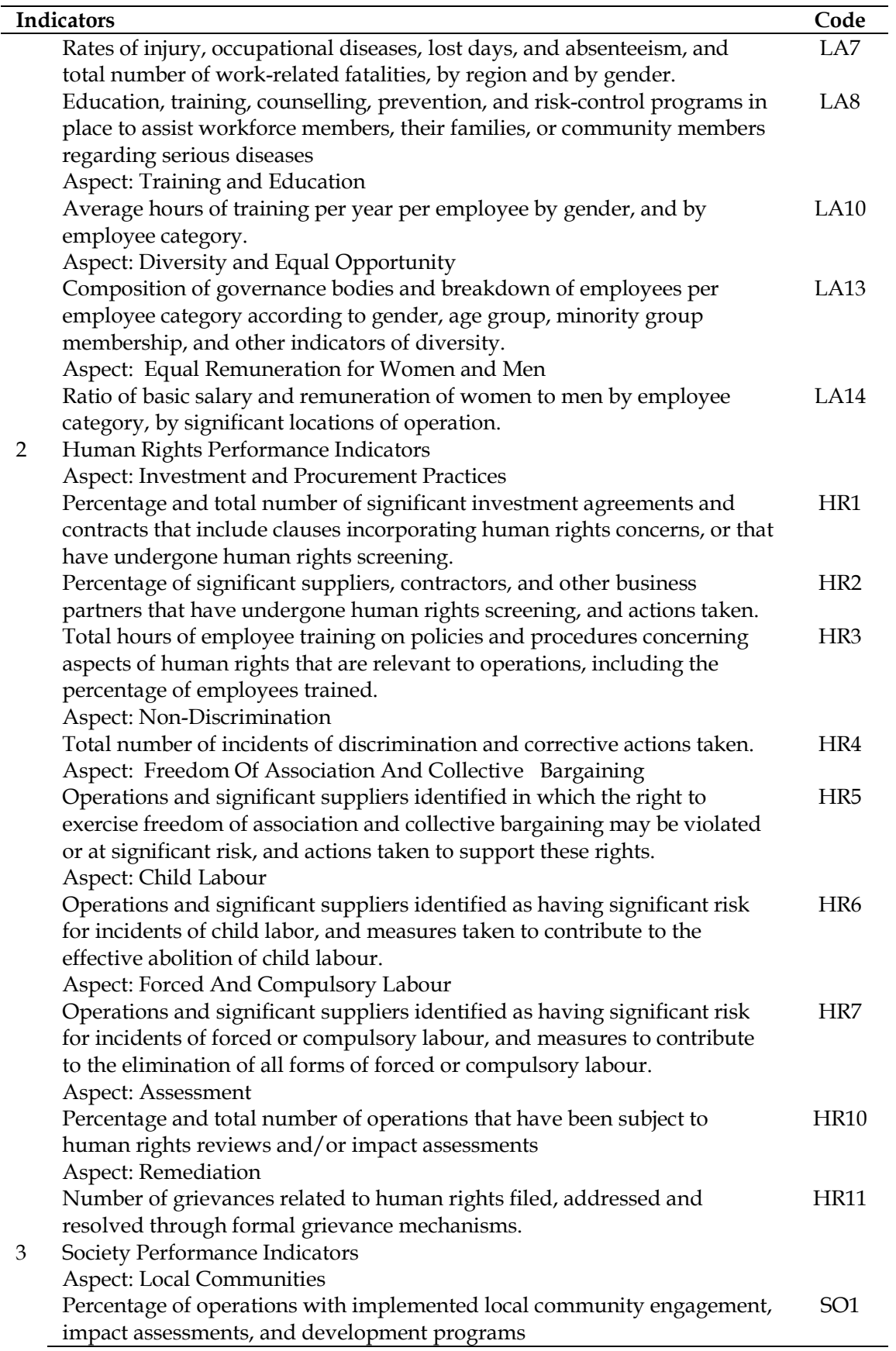




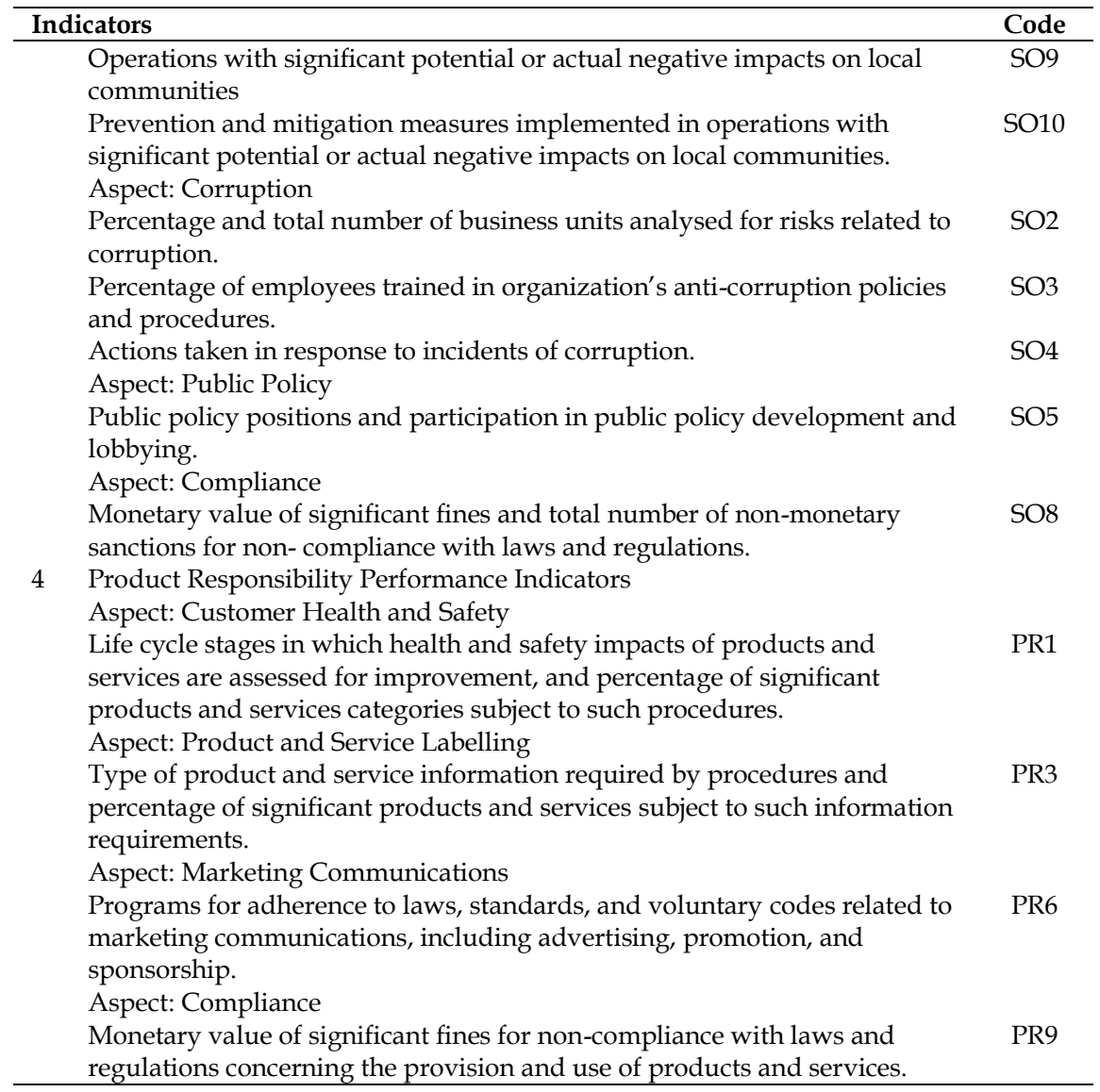


Appendix 2: Sample Selection

\begin{tabular}{lll}
\hline Industry & No. of companies listed & No. of sample companies \\
\hline Textiles & 53 & 20 \\
Cement & 7 & 5 \\
Foods and Allied & 17 & 6 \\
$\begin{array}{l}\text { Pharmaceuticals and } \\
\text { Chemicals }\end{array}$ & 31 & 10 \\
Bank & 30 & 10 \\
\hline Total & $\mathbf{1 3 8}$ (as of December 2018) & $\mathbf{5 1}$ \\
\hline
\end{tabular}

Appendix 3: Overall Sustainability Reporting Disclosures by the Bangladeshi companies (Figure 1)

\begin{tabular}{llll}
\hline Particulars & $\begin{array}{l}\text { Overall } \\
\text { Sustainability } \\
\text { Reporting }\end{array}$ & $\begin{array}{l}\text { Specific disclosure } \\
\text { in Environment } \\
\text { aspects }\end{array}$ & $\begin{array}{l}\text { Specific } \\
\text { disclosure in } \\
\text { Social aspects }\end{array}$ \\
\hline $\begin{array}{l}\text { Companies with } \\
\text { disclosures in at least one } \\
\text { content }\end{array}$ & $44(86.27 \%)$ & $39(76.47 \%)$ & $36(70.59 \%)$ \\
$\begin{array}{l}\text { Companies with no } \\
\text { disclosure }\end{array}$ & $7(13.73 \%)$ & $12(23.53 \%)$ & $15(29.41 \%)$ \\
$\begin{array}{l}\text { Total companies } \\
\text { considered our study }\end{array}$ & $51(100 \%)$ & $51(100 \%)$ & $51(100 \%)$ \\
\hline
\end{tabular}


Sustainability reporting disclosure practices among Bangladeshi companies in line with global...

Appendix 4: Specific disclosures on Environment and Social aspects by the Bangladeshi companies

\begin{tabular}{|c|c|c|c|c|c|c|c|c|c|c|c|c|c|c|c|c|c|c|}
\hline \multirow[b]{3}{*}{ 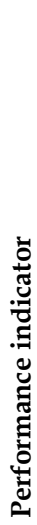 } & \multirow{2}{*}{\multicolumn{3}{|c|}{ Overall }} & \multicolumn{15}{|c|}{ Industry Wise } \\
\hline & & & & \multicolumn{3}{|c|}{ Textiles } & \multicolumn{3}{|c|}{ Cement } & \multicolumn{3}{|c|}{$\begin{array}{l}\text { Foods and } \\
\text { Allied }\end{array}$} & \multicolumn{3}{|c|}{$\begin{array}{l}\text { Pharmaceut } \\
\text { icals and } \\
\text { Chemicals }\end{array}$} & \multicolumn{3}{|c|}{ Bank } \\
\hline & 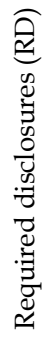 & 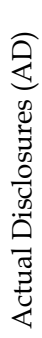 & 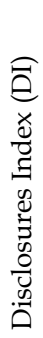 & 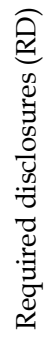 & 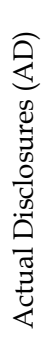 & 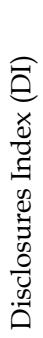 & 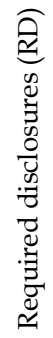 & 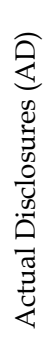 & 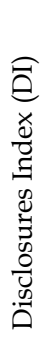 & 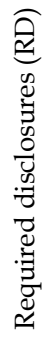 & 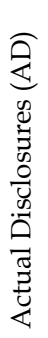 & 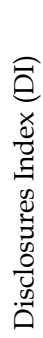 & 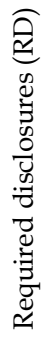 & 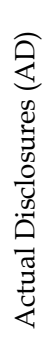 & 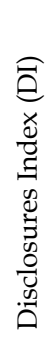 & 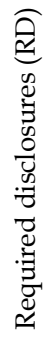 & 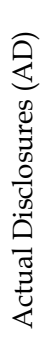 & 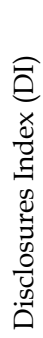 \\
\hline 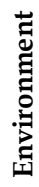 & $\widehat{\infty}$ & ร & $\stackrel{\stackrel{\Im}{7}}{\stackrel{7}{ت}}$ & ஜ̊ำ & 文 & $\begin{array}{l}\stackrel{0}{8} \\
\stackrel{0}{0}\end{array}$ & $\infty$ & $\stackrel{\infty}{\sim}$ & $\begin{array}{l}\stackrel{\circ}{\infty} \\
\stackrel{\sim}{\sim}\end{array}$ & రి & $\infty$ & ণ̊ & $\stackrel{R}{\Re}$ & $n$ & 遖 & $\stackrel{R}{\Omega}$ & $\approx$ & $\stackrel{\circ}{\circ}$ \\
\hline . & $\begin{array}{l}\vec{\infty} \\
10 \\
\stackrel{1}{1}\end{array}$ & 3 & 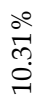 & તิ & กิ & $\begin{array}{l}\stackrel{0}{6} \\
\stackrel{1}{10}\end{array}$ & 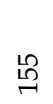 & กิ & $\begin{array}{l}\stackrel{\circ}{2} \\
\stackrel{+}{+}\end{array}$ & $\underset{\infty}{\infty}$ & $\infty$ & $\begin{array}{l}\stackrel{0}{0} \\
\text { On } \\
+i\end{array}$ & $\stackrel{\circ}{\text { m }}$ & ని & ัํํ & $\stackrel{\circ}{\frac{0}{n}}$ & $\stackrel{\infty}{x}$ & 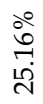 \\
\hline 苞 & 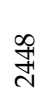 & ปู & $\begin{array}{l}\stackrel{\circ}{0} \\
\stackrel{0}{0} \\
\stackrel{1}{1}\end{array}$ & ஜํ & প & $\begin{array}{l}\circ 0 \\
\infty \\
\\
\sigma\end{array}$ & ন & 아 & 离 & $\stackrel{\infty}{\infty}$ & 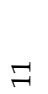 & $\begin{array}{l}\stackrel{\circ}{N} \\
\infty \\
\dot{0}\end{array}$ & 这 & บ & $\underset{\text { ஸे }}{\stackrel{\circ}{10}}$ & $\underset{+}{\infty}$ & L & $\begin{array}{l}\stackrel{0}{\Omega} \\
\text { ลू }\end{array}$ \\
\hline
\end{tabular}


Appendix 5: Main themes or issues of Environment Dimension by the Bangladeshi companies

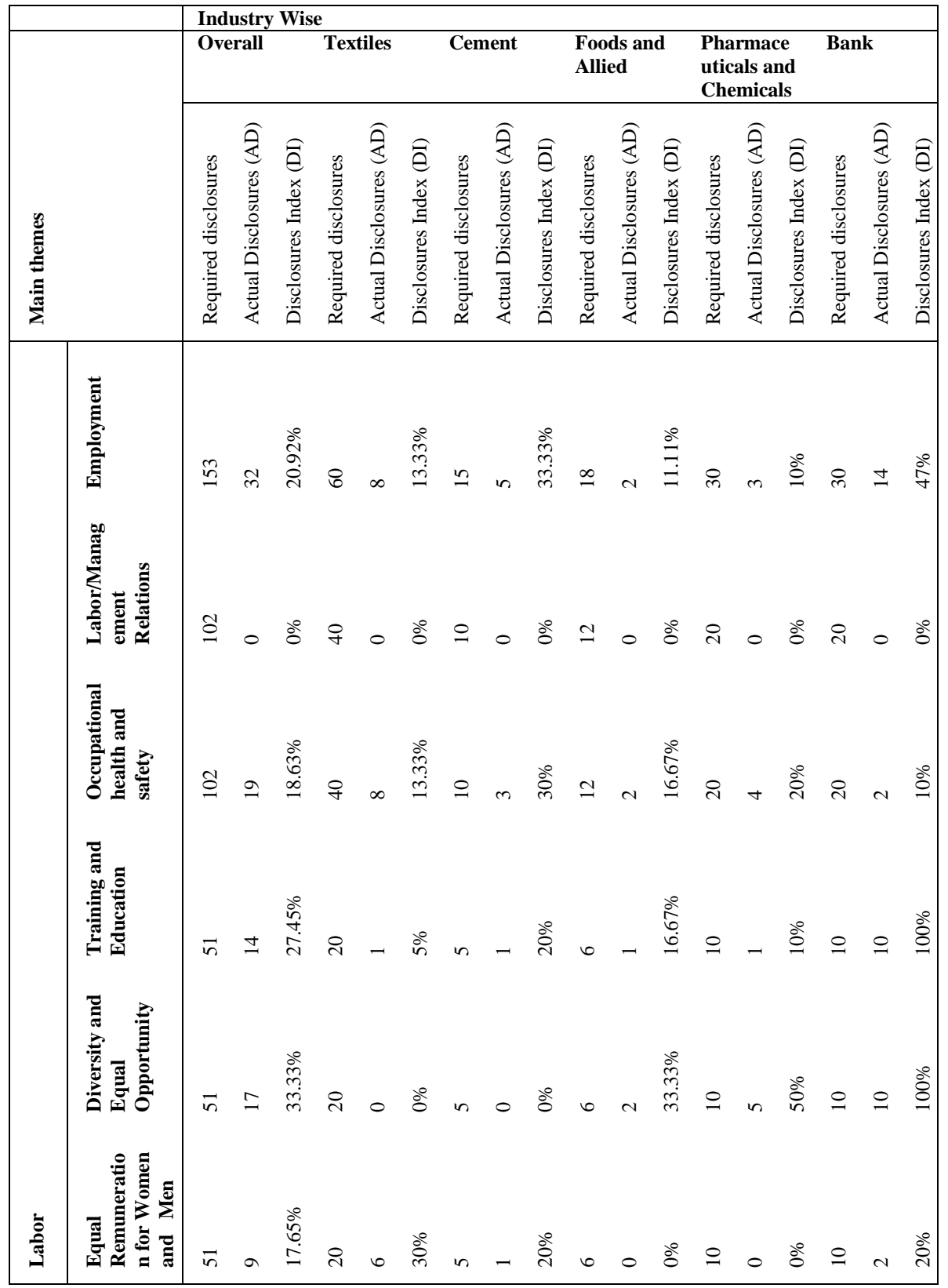


Sustainability reporting disclosure practices among Bangladeshi companies in line with global...

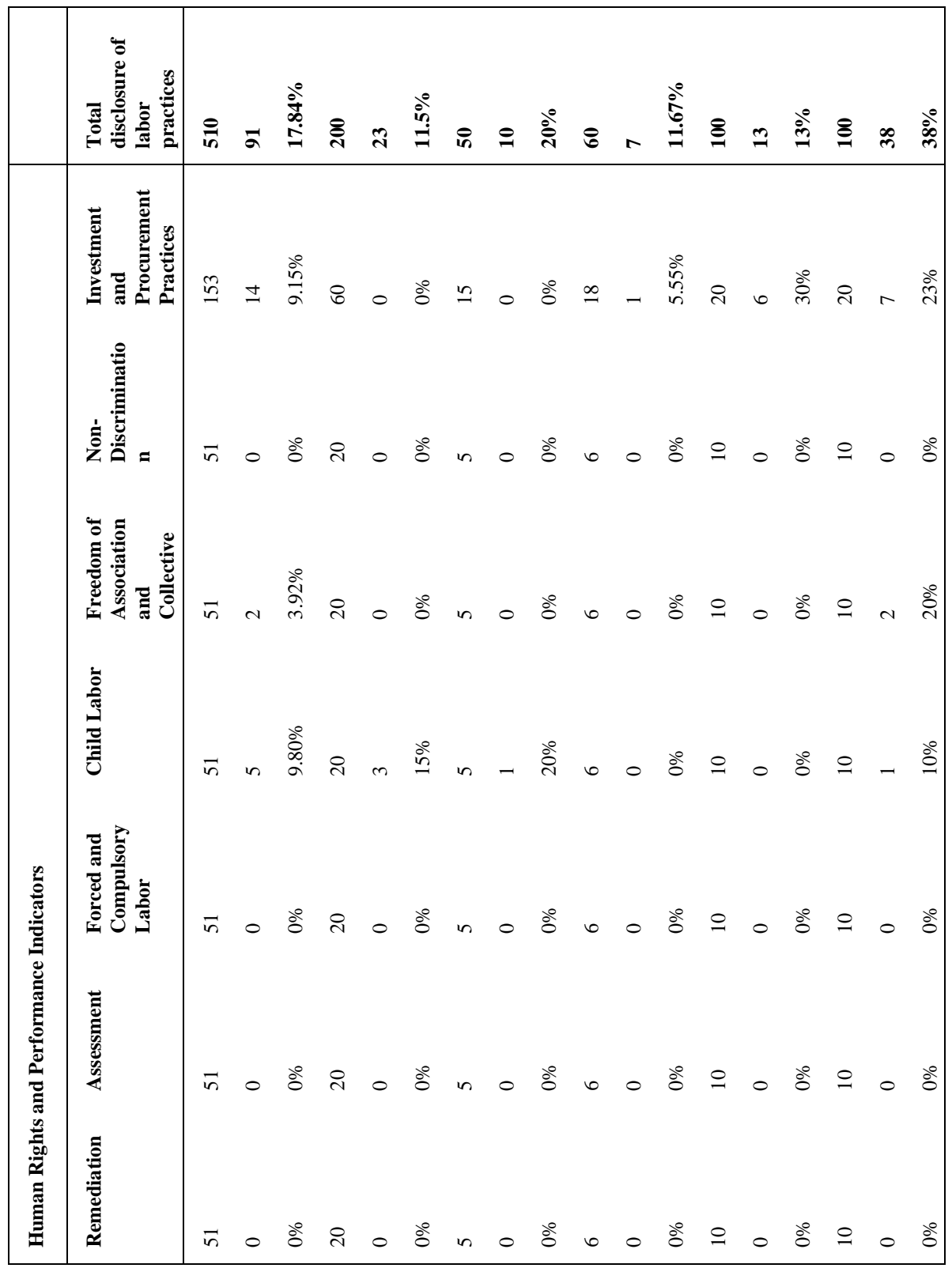

95 
S. K. Dis et al. (2021) / Asian Journal of Accounting Perspectives

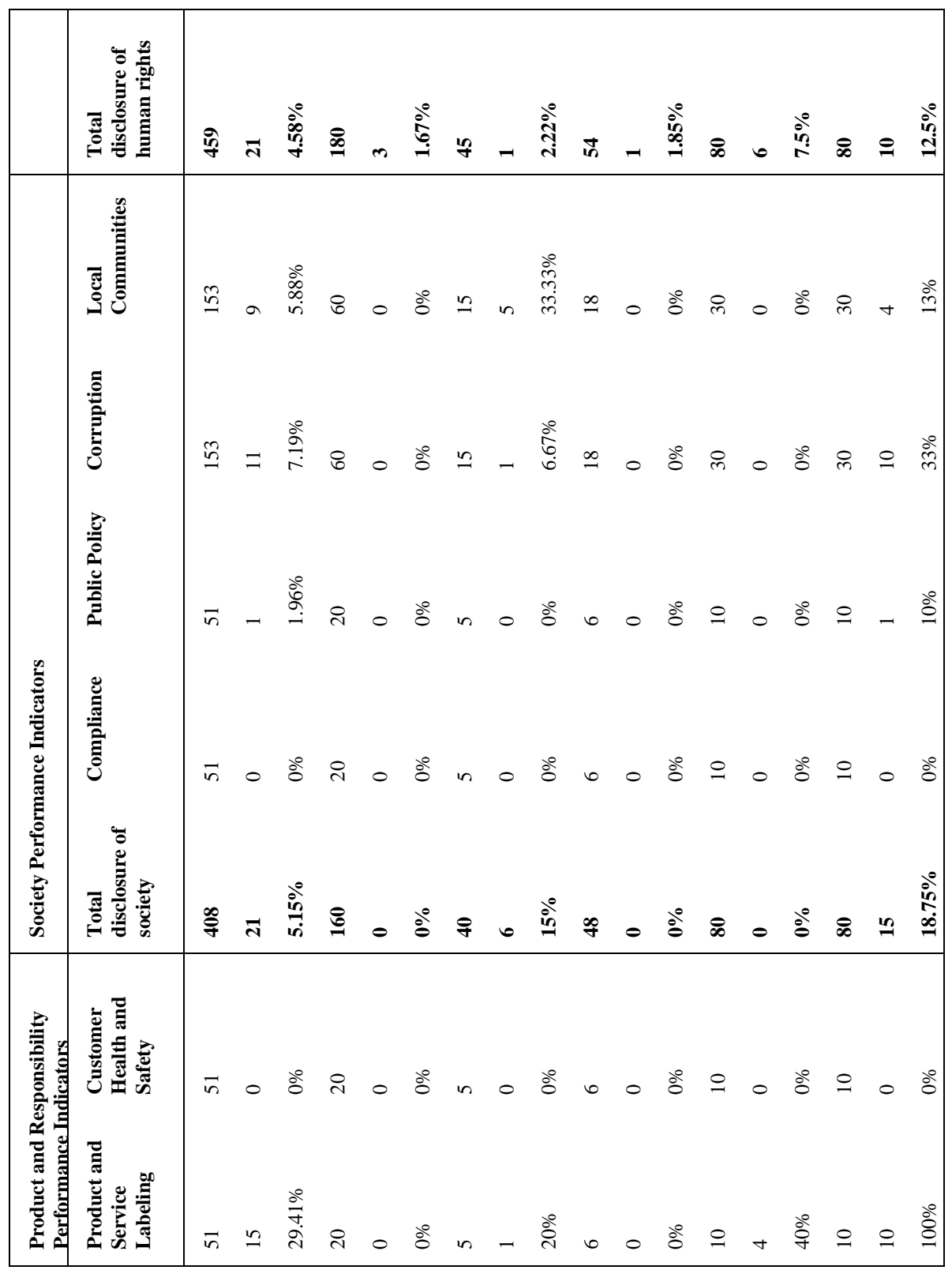

96 
Sustainability reporting disclosure practices among Bangladeshi companies in line with global...

\begin{tabular}{|c|c|c|c|c|c|c|c|c|c|c|c|c|c|c|c|c|c|c|}
\hline 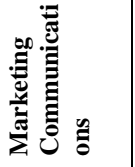 & $\bar{n}$ & $\underline{-}$ & $\underset{m}{\stackrel{\circ}{n}}$ & సิ & 0 & $\stackrel{8}{0}$ & $n$ & $\nabla$ & $\stackrel{\infty}{\infty}$ & 0 & 0 & 80 & 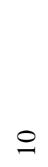 & 0 & \&̊ & 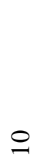 & 0 & 8 \\
\hline 这 & $\bar{n}$ & 0 & 8̊ & సิ & 0 & $8^{\circ}$ & in & 0 & 80 & 0 & 0 & $\vdots 0$ & 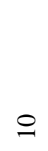 & 0 & \&̊ & 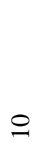 & 0 & 8 \\
\hline 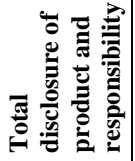 & ষ্ণ & $\bar{m}$ & 苗 & 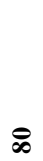 & 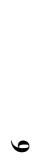 & $\begin{array}{l}\text { is } \\
\text { in }\end{array}$ & సి & 10 & $\begin{array}{l}80 \\
\ddot{\alpha}\end{array}$ & $\vec{N}$ & $\theta$ & $\stackrel{\circ}{0}$ & P & $\nabla$ & $\stackrel{\circ}{\varrho}$ & F & 으 & in \\
\hline
\end{tabular}

